\title{
Ludvig Holbergs opgor med Antikkens helteideal
}

Antikken har leveret en af historiens mest sejlivede heltedefinitioner i skikkelse af krigerhelten. Krigerheltens centrale dyd - hans tapperhed er stadig en væsentlig bestanddel, når vi i dag forsøger at definere nutidens helte. Historisk har dette fokus på Antikkens helteideal dog også mødt stor modstand.

Navnlig ikonet for dansk-norsk oplysningstid Ludvig Holberg, hvis fascination af helte og skurke gennemsyrer store dele af hans forfatterskab, tog afstand fra Antikkens idealisering af tapperhed. Ifølge Holberg forveksledes tapperhed ofte med hævngerrighed - en last der normalt tillagdes en skurk.

Ved én lejlighed hellige Holberg et helt værk til at præsentere et alternativt helteideal til Antikkens. Det blev en af hans populæreste bøger, der kendes under navnet Heltehistorier. Bogen består af tolv dobbeltbiografier og bærer den fulde titel: Adskillige store Heltes og berommelige Mands, sar Orientalske og Indianske sammenlignede Historier og Bedrifter efter Plutarchi Maade (1739). Som man ser, forekommer ordet Heltehistorier ikke direkte i titlen, og værket behandler så sandelig også skurke, men mere derom senere.

I forhold til tidligere tiders popularitet er Heltehistorier i dag lidet kendt uden for Holberg-kredse. Selv blandt Holberg-kendere er det ikke mange, der har beskæftiget sig med værkets indhold. Årsagen til dette findes ikke nødvendigvis i Heltehistoriers receptionshistoriske aftryk, men snarere i en generel prioritering af den skønlitterære Holberg og medfølgende negligering af hans historiske og moralfilosofiske forfatterskab. Derfor anser mange i dag Holberg som Danmark-Norges mest betydningsfulde komediedigter, mens folk er mindre bekendte med, at ca. halvdelen af hans forfatterskab bestod af historiske værker, og at han i 1730 tildeltes professoratet $\mathrm{i}$ historie på Københavns Universitet.

Uanset hvor ukendt Heltehistorier er i dag, så er det dette værk, der må danne udgangspunkt for enhver diskussion af Holbergs helte- og skurkebegreb. 


\section{Hvem er heltene og skurkene?}

Kaster man et blik på den relativt begrænsede del af Holberg-forskningen, der har beskæftiget sig med hans heltebegreb, støder man på en overraskende høj grad af uenighed om, hvem af de i alt 24 biograferede personer i Heltehistorier, der er helte, og hvem der er skurke.

Anne E. Jensen har f.eks. konkluderet, at Holberg i parallelbiografien om bøhmeren Scanderbeg og hussiten Ziska favoriserede Scanderbeg, men at: "begge efter Holbergs mening var sande helte" (Jensen 1984: 112). I F.J. Billeskov Jansens Holberg som Epigrammatiker og Essayist er Ziska dog, pga. sin hævngerrighed, inkluderet i Heltehistoriers skurkegalleri (Billeskov Jansen 1938-1939: II, 38). Samme uenighed gør sig gældende om de to mongolske regenter Cingiskan (Djenghis Khan) og Tamerlan (Timur Lenk), som forskerne bag Dansk litteraturs historie 1100-1800 (2007) opfatter som afskrækkende tyranner (Pedersen et al 2007: 466), mens Peter Brask i sit studie af Heltehistoriers persongalleri hælder mod, at Holberg i tråd med 1700-tallets trend skildrede Tamerlan positivt som den: "deistisk tolerante fyrste, der gerne påhører tvær-konfessionelle samtaler" (Brask 2006: 73). Brask mener desuden, at størstedelen af Heltehistoriers biograferede personer blev fremstillet som skurke (Brask 2006: 68), hvilket står i skærende kontrast til Billeskov Jansen, der kun har identificeret tre skurke i værket (Billeskov Jansen 1938-1939: II, 38).

Den manglende konsensus i forhold til helte- og skurkedefinitionen er udgangspunktet for denne artikel. Formålet er at præsentere en mere differentieret og bedre funderet forståelse af Holbergs heltebegreb, sådan som det kommer til udtryk i Heltehistorier. Der er derfor ikke tale om en udtømmende analyse af Holbergs helte- og skurkebegreb i hele forfatterskabet, da omfanget af en sådan analyse sprænger rammerne for denne artikel.

Flere af de 24 biograferede personer skal hverken ses som helte eller skurke, men - som værkets fulde titel antyder - som berommelige Mand. Ordet berommelige skal i denne sammenhæng forstås som en neutral betegnelse for personer, der har haft stor indflydelse på historiens gang, og hvis tilstedeværelse i værket retfærdiggøres ved, at de bidrager til forståelsen af den enkelte parallelbiografis moralfilosofiske emne uden af den grund at være hverken helt eller skurk. 
Pga. dette er der heller ikke tale om en slavisk gennemgang af hver enkelt biografi. I stedet præsenteres en syntetiseret analyse, hvor fokus vil være på de biografier, der er essentielle for forståelsen af Holbergs helte- og skurkedefinitioner.

\section{Den parallelbiografiske metode og udvalget af helte og skurke}

Heltebistoriers formål er at belære læseren om bestemte moralfilosofiske emner. Hver parallelbiografi indledes med en præsentation af et moralfilosofisk emne, som de efterfølgende to biografier underbygger. Biografierne afsluttes med en sammenligning af de biograferedes dyder og laster. Metoden havde Holberg hentet fra Plutarchs Vitae parallelae, men i valget af biograferede personer afveg Holberg fra Plutarch. Mens Plutarch kontinuerligt havde sammenparret en græker med en romer, så fandt Holberg størstedelen af sit persongalleri i Asien og Amerika.

Hvad fik så Holberg til at finde sine helte, og skurke i ikke-europæiske lande? Han var bevidst om, at Heltehistoriers persongalleri afveg fra det forventelige og at "Nogle skulde maa skee vel censurere dette Verk, og sige: hvi har Autor ikke heller taget Europæiske Helte, af hvis Historier meer er at lære, og hvis Læsning er behageligere [...]" (Holberg 1913-1963: XI, 7). Holberg foregreb denne kritik med et argument om værkets nyhedsværdi:

[...] som de Romerske og Græske, samt de andre Europæiske Heltes Bedrifter ere saa bekiendte, saa er det ikke andet, end at opkaage hvad utallige andre Skribentere tilforn have ført i Pennen, hvorudover man udi dette Verk har fundet for got, heller at tale om Orientalske og Indianske Heltes Bedrifter, saasom de samme ere os meer ubekiendte, og derfor smage af noget som er nytt. Visse af disse Historier ere og ikke mindre nyttige end behagelige at læse; ja man kand sige, at der ere faa Europæiske Historier, der sætte en Læser meer i Bevægelse, end Montezumæ, Atapalibæ, Myrr-Weis og Magmuds (Holberg 1913-1963: XI, 7).

Holberg var altså bevidst om, at det "eksotiske" udvalg kunne afstedkomme undren blandt hans samtidige, og her fik han ret. I den eneste samtidige danske anmeldelse rostes Holberg for sin metodi- 
ske opbygning og moralfilosofiske agenda, men anmeldelsen afsluttedes med et ønske om, at:

[...] sligt et Arbeyde maatte komme for Lyset om Europæiske berømmelige Christne Mænd, enten fra Autor selv, som saavel i dette Skrift, som i Dannemarks Riges Historie har viist store Prøver paa sit store og rare Pund, som i andet saa i sær ved store Mænds Sammenligning, eller og fra en anden, der enten besad samme Talent eller kunde opnaae endeel deraf, da man sluttelig skulde vente et frugtbarere Morale, end af Hedenske og andre U-Christne Mrnds Levnets Historie (Bang 1743: 444).

Det "eksotiske" kunne derfor med fordel udskiftes med et mere europæisk orienteret persongalleri. Mere rammende var den svenske publicist Carl Christoffer Gjörwells kritik, der kort tid efter Holbergs død konstaterede, at valget af primært ikke-europæiske helte afspejlede en generel frygt fra Holbergs side. En frygt, der skyldtes, at det ikke ville være muligt at udelade svenske heltekonger som Gustav Vasa og Gustav Adolf, hvis grundlaget for Heltehistoriers persongalleri havde været europæisk. De svenske heltekongers storhed ville ikke kunne matches med danske pendanter, hvorved Holberg ifølge Gjörwell bevidst havde fravalgt et europæisk fokus (Gjörwell 1754: 46).

Til trods for overrepræsentationen af ikke-europæere havde Holberg stadig fundet plads til syv berømtheder, der var af europæisk herkomst. Blandt disse er navnlig biografierne om Petrus Alexiovitz (Peter den Store) og Socrates interessante i forhold til dette studie, idet der eksisterer en bred konsensus blandt både ældre og nyere forskningslitteratur om, at den russiske zar og den græske filosof var blandt Holbergs fremmeste helteskikkelser. I visse tilfælde har dette genereret et uhensigtsmæssigt fokus på de to biografier, når Holbergs helteideal skulle bestemmes (se f.eks.: Krüger 1968: 173-176; Langslet 2002: 205-206). Der skal ikke herske tvivl om, at Petrus Alexiovitz og Socrates hørte til blandt Heltehistoriers største helte, men de var det som henholdsvis statsmand og Philosophus, og værket indeholder flere heltedefinitioner end disse. Det er derfor nødvendigt at differentiere mellem forskellige typer helte (og skurke), hvis vi skal forstå Holberg ret.

Her bør det indskydes, at ord som skurk og deslige sjældent 
forekommer i Heltehistorier eller det øvrige faglitterære forfatterskab, og at et klart defineret skurkebegreb synes vanskeligt at identificere. I stedet talte Holberg om udyd (laster) eller onde (dårlige) eksempler: "ligesom man af gode Regenteres Exempler opmuntres til Dyd, saa afskrækkes man af de ondes Exempler fra Udyd, hvorudover begge slags Historier sigte til en Scopum [samme mål]" (Holberg 1913-1963: XI, 7).

\section{Heltehistorier - et uoriginalt eller originalt værk}

Vel har man forsøgt at giøre saadanne Prøver med een og anden Helt, som man har sammenparret med en anden, men ingen, som mig er bekiendt, har ex Professo [på embeds vegne] søgt at forfatte noget heelt Verk over moderne Heroes, og lignet dem sammen paa den Maade, som Plutarchus har giort med Græske og Romerske berømmelige Mænd: og er det derfore, at dette mit ringe Verk i Henseende til Imitation kand, maa skee, finde een og andens Bifald (Holberg 1913-1963: XI, 8).

Således definerede Holberg sin rolle i den parallelbiografiske tradition. Hvilke foregående parallelbiografiske forsøg, Holberg hentydede til, kan ikke siges med sikkerhed, men der forefindes visse ledetråde, f.eks. i Johann Christoph Kinds forord til den tyske oversættelse af Plutarchs Vitae parallelae fra 1745. Heri præsenteredes en kort historiografisk gennemgang af foregående eksempler på parallelbiografiske værker. Det mest samtidige eksempel var Holberg, men flere franske fortilfælde kunne nævnes: historikeren Antoine Varillas, litteraturkritikeren Charles de Saint-Évremond, teologen Daniel Lombard og adelsmanden Paul de Rapin (Plutarch \& Kind 1745: Vorrede). Så da Holberg i 1739 udgav sine parallelbiografier om helte, skurke og berømmelige mænd, skrev han sig ind i en allerede etableret og primært fransk tradition, men de franske forgængeres forsøg var - som Holberg havde påpeget - enkeltstående forsøg og ikke større værker bestående af adskillige parallelbiografier.

Francis Bull har bemærket, at værkets moralfilosofiske element - dvs. parallelbiografiernes forberedelser - var Holbergs eget unikke bidrag til Plutarchs parallelbiografiske metode, mens Leiv Amundsen og navnlig Herman Jæger har antaget, at forberedel- 
serne var inspireret af Charles-Irénée Castel de Saint-Pierres skrifter (Amundsen 1925: 11; Jæger 1914: 203-204). Alle tre synes dog at have overset, at allerede Plutarch indledte nogle af sine parallelbiografier med at introducere et moralfilosofisk emne, der - ligesom hos Holberg - fungerede som omdrejningspunkt for den biografiske sammenligning. At Saint-Pierre skulle have været den egentlige kilde til Holbergs opdeling er usandsynligt, idet Saint-Pierres hensigt var at supplere hele Plutarchs biografiske værk med én indledende afhandling om den store mand over for den berømmelige. Samtidig skulle indledningerne til parallelbiografierne placeres efter sammenligningerne (Billeskov Jansen 1938-1939: II, 37-39, 256).

Jæger har ligeledes ment at kunne påvise, at Holbergs helteideal var en kopi af Saint-Pierres ditto. Hvorvidt Jægers påstand kan be- eller afkræftes skal ikke afgøres her, da et sådant studie fordrer sin egen selvstændige artikel. Det skal dog nævnes, at Jæger med henvisning til Saint-Pierres Ouvrajes de politiques afviser Holbergs originalitet i forhold til kritikken af det antikke helteideal i parallelbiografien mellem Lucius Sylla og Cæsar (Jæger 1914: 204), men Jæger følger ikke sin påstand op med en tilbundsgående sammenligning af Heltehistorier og Saint-Pierres skrifter, hvilket må være en forudsætning for, om påstanden kan underbygges. Kan Jægers betragtninger bekræftes, vil der være tale om et gennembrud i forhold til forståelsen af Heltehistorier og Holbergs opgør med Antikkens helteideal.

\section{Opgøret med Antikkens helteideal}

Netop i Heltehistorier finder vi Holbergs mest iøjefaldende moralfilosofiske kritik af Antikkens helteideal, der ifølge Holberg fungerede som rettesnor for samtidens gængse forståelse af en helt. Kritikken kom først og fremmest til udtryk i fortalen til parallelbiografien mellem Scanderbeg og Ziska, hvor Holberg bl.a. fremførte følgende:

Blant mange Ting, som misbruges udi daglig Tale og Skrifter er den Titul af Helt eller Heros. Homerus, som Poëter og Moralister foresætte sig som en Modell at efterfølge, haver lagt første Grundvold til denne Irring, i det han har udi Heroiske Vers forestillet, som Dyders 
og Tapperheds Exempler visse Mænd, hvis Bedrifter og Gierninger heller burte nedgraves i Forglemmelse, og hvis Levnet aldeeles ingen Overeensstemmelse har med den rette Heroismo; thi, skal Achilles, skal Ulysses være Heroës eller slig Helte, da bliver Definitionen saadan: en Helt er en Mand, der røver, plyndrer og slaaer Mennesker ihiel med saadan bestandig Lykke og Succés, at ingen drister sig til eller formaaer at fordre ham til Regnskab derfor, men maa overlade GUd Hevnen. Eller, en Helt er en Mand, der ved Sviig og Underfundighed kommer til Rigdom og Velstand, og sætter sig selv og sit Land i den Stand, at han bliver en Skræk for alle sine Naboer (Holberg 1913-1963: XI, 148).

Afvisningen af Antikkens helteideal begrænsede sig ikke til sagnheltenes univers, men rettede sig ligeledes mod to af verdenshistoriens største erobrere - Alexander den Store og Cæsar. Selvom begges krigshandlinger havde forårsaget død og ødelæggelse, blev selvsamme vederstyggeligheder tolket som tapperhed, mens en egenskab som besindighed sjældent ophøjedes til en heltedyd. Dette var en central pointe for Holberg, hvis eget helteideal var uforeneligt med den gængse krigshelt:

En Heros er en udi Dyder fuldkommen Mand, som af Himmelen er dannet heller til Menneskets Frelse og Conservation, end til dets Ødeleggelse, og er derfore en god Huusfader, der har bragt et Douzaine vel optugdede Børn til Verden, nærmere ved Heroismum, end den store Alexander, der opofrede fast million Mennesker. Skal Heroismus bestaae $\mathrm{i}$ at løbe Hovedet mod Veggen og foragte sit og andres Liv, saa kand man give den Æres Titul til ligesaa mange umælende Dyr, som Mennesker (Holberg 1913-1963: XI, 149).

I parallelbiografien mellem Cæsar og Lucius Sylla, roste Holberg - i modsætning til Plutarch - sidstnævnte pga. hans borgersind og dømmekraft, mens Holberg tog afstand fra Cæsars ærgerrighed og krigsbedrifter (Bull 1913: 114-115). At Holberg ikke kunne forlige sig med det helteideal, Cæsar repræsenterede, betød ikkem at Holberg kategoriserede ham som skurk. Ligesom Cingiskan, Tamerlan, Zoroaster (Zarathrustra) og andre anerkendte Holberg Cæsars berømmelige karakterer, men hans bedrifter rakte ikke til at være andet end berømmelige.

Som Anne E. Jensen har bemærket var opgøret med Antikkens helteideal ikke nyt. I hendes tilbundsgående analyse af Holbergs 
komedie Olysses von Ithacia (ca. 1723) identificerer hun to væsensforskellige heltedefinitioner: den antikke helt Olysses og antihelten Chilian - Olysses tro hjælper. Antihelten skal ifølge Jensen ses som en person, der lever med respekt for både sit eget og andres liv, hvilket står i skærende kontrast til den almene forståelse af antihelten - en person der ikke formår at leve op til helteidealet. Denne begrebsforvirring skal ses i lyset af komediens kritiske og satiriserende holdning til Antikkens helteideal, hvis betydning blev vendt på hovedet af Holberg, således at Olysses helteskikkelse fremstilledes som antihelten ud fra den gængse forståelse af begrebet. Jensens analyse er interessant, da hun kobler den satiriske kritik af den antikke helt sammen med den i Heltehistorier moralfilosofiske og historiske kritik af selvsamme helteskikkelse (Jensen 1984: 96-129). Hvis elementer af Holbergs kritik af det antikke helteideal kan spores tilbage til hans tidlige komedier, skal man derfor være varsom med at antage, at denne kritik - som Jæger påstår - var kopieret fra Saint-Pierres skrifter.

Hvilket helteideal erstattede Holberg så det antikke med? Her er svaret snarere en pamflet af forskellige helteidealer end én klart afgrænset helteskikkelse.

Vender vi tilbage til parallelbiografien mellem Scanderbeg og Ziska, synes svaret ellers ligetil. Scanderbeg var pga. sin tapperhed og milde natur: "den største Helt, som Naturen har dannet, og ingen hverken udi gamle eller nye Historier kand lignes med ham" (Holberg 1913-1963: XI, 172), mens Ziska portrætteredes som eksemplet på Antikkens helteideal i den mest ekstreme forstand. Hans gerninger gjorde ham til en af sin tids største feltherrer, men hans hævntørst: "gik jo for vit, og at de gruelige Executioner, som skeede, viise, at denne Mand inclinerede til Haardhed, som undertiden gik indtil Barbarie" (Holberg 1913-1963: XI, 156). I det store hele fordømte Holberg Ziskas handlinger og tegnede et så negativt billede af feltherren, at det har fået Billeskov Jansen til at inkludere ham i Heltehistoriers skurkegalleri (Billeskov Jansen 1938-1939: II, 38). Ziska var den nådeløse hævner, hvis hævngerrighed forveksledes med tapperhed, og

[...] gaaer man videre, og tager sig for at examinere Heroiske Qvaliteter, da kand den sidste [Ziska] i ingen Ting lignes med den før- 
ste [Scanderbeg], hvis heele Levnet var prydet med Mildhed, Naade, Urets Forglemmelse, og oprigtige Heroiske Dyder: saa at han syntes ikke at føre Krig for at indlegge Ære, men for at efterleve sin Pligt, og anvende det store Pund, som GUd havde betroet ham til at standse den grummeste Fiende [Det Osmanniske Rige], som Christendommen nogen Tid har haft (Holberg 1913-1963: XI, 173).

Holberg skildrede derfor Scanderbeg som den ypperste af alle helte, men der var tale om en betinget heltetitel i den forstand, at hans titel alene var et resultat af ædle krigsbedrifter. Scanderbeg var historiens største krigshelt, men ikke mere end dette. Han excellerede hverken ud i statsmandssager eller korrekt filosofisk levevis, hvorved betegnelser som fuldendt regent eller Philosophus ikke kunne tilskrives ham.

I parallelbiografierne mellem den mogulske regent Akebar og den russiske zar Petrus Alexiovitz samt mellem grækerne Epaminondas og Socrates når Heltehistorier sit moralfilosofiske højdepunkt i fremstillingen af henholdsvis den fuldendte regent og den ægte Philosophus.

Omdrejningspunktet for Holbergs fuldkomne regent var en moralfilosofisk overvejelse over, hvordan lidet respekterede folkeslag kunne forvandles til højtagtede og frygtede folkeslag. Centralt for denne omvæltning var den stærke regent, der gik foran med eget eksempel. Skildringen af Akebar og Petrus Alexiovitz var derfor en detaljeret gennemgang af hver regents dyder, hvor deres ambition og evne til at forbedre samt styrke deres rigers ydre og indre forhold fremhævedes (Holberg 1913-1963: XI, 90-145). ”Den første [Akebar] studerede paa at blive selv en fulkommen Mand, den anden [Petrus Alexiovitz] paa at giøre sit heele Folk fuldkommen, saa at den første kand kaldes større Menneske, den sidste større Konge” (Holberg 1913-1963: XI, 146).

Den ægte Philosophus eller vise mand defineredes ud fra hele fjorten karakteregenskaber, som var:

[...] grundig Lærdom, Herredom over sine Affecter, tækkelig Omgiængelse, Attraae [lyst] til at forfremme sin Næstes Velfærd, Vindskibelighed [flid, foretagsomhed] $\mathrm{i}$ at efterforske Sandhed, Frimodighed $i$ at prædike den samme, Ærbarhed uden Affectation, Kundskab om sig selv, liden Attraae efter verdslig og forfængelig Ære, og Fornøyel- 
se med sin Stand og Vilkor, ikke at foragte Rigdom og Penge ey heller at dyrke dem, ringe Tanker om sin egen Person, Medlidenhed mod Vildfarende, Omsorg for at conservere sit Liv og Sundhed, ingen utidig Begierlighed til at døe, og ingen Frygt mod Dødens Ankomst, saa at hans Symbolum i den Henseende maa være: Nec cupio, nec metuo [jeg begærer ikke, jeg frygter ikke]. Kiærlighed til Fædernelandet og Lydighed mod Øvrigheden; Taalmodighed udi Lidelser og Urets Forglemmelse, Bestandighed uden Haardnakkenhed og andre deslige Qvaliteter (Holberg 1913-1963: XI, 451-452).

Der var her tale om et for Holberg personligt Philosophus-ideal (Billeskov Jansen, 1938-1939: II, 43), hvilket både Socrates og Epaminondas efterlevede til punkt og prikke. Hvorfor Socrates så alligevel overgik Epaminondas skyldtes udelukkende førstnærntes baggrund.

Påfaldende for begge parallelbiografiers vurdering af de biograferede var den fokus Holberg tillagde geografiske, tidsmæssige og kulturelle betingelser. Socrates måtte gennem praktisk øvelse lære sig selv de dyder, der gjorde, at hans: "heele Liv var en bestandig Prædiken og Opmuntring til Dyd og Duelighed. Det er derudi han er større ikke alleene end Epaminondas, men end ogsaa end alle andre Philosophi; og er hans Lærdom som en Kilde, hvoraf den sundeste Philosophie flyder" (Holberg 1913-1963: XI, 499). Både Akebars og Petrus Alexiovitz' bedrifter var imponerende, men det faktum, at de handlede anderledes end deres opdragelse og kulturelle baggrund foreskrev, ophøjede deres gerninger, hvorved man i Petrus Alexiovitz' tilfælde kunne: "sige, at han har overgaaet alle Regentere, og ansee ham som een, hvilken GUd paa en umiddelbar Viis opvakte for at oplyse en stor Part af Verden." (Holberg 19131963: XI, 145).

Betingelser som arv og miljø var derfor centrale, når Holberg vurderede sine helte, skurke og berømmelige personligheders positive og negative karakteregenskaber, men det var ikke ensbetydende med, at dyder og laster var foranderlige. I Moralske Tanker (1744) advarede Holberg f.eks. mod at definere dyder og laster ud fra kulturelle og tidsmæssige omstændigheder (Holberg 1913-1963: XIV, 292-296). Kønsbestemmes kunne de heller ikke, hvilket udredtes i parallelbiografien mellem den ægyptiske herskerinde Zenobia og den russiske dronning Catharina Alexiewna (Holberg 1913-1963: XI, 306-310). En dyd var derfor altid en dyd og en last altid en last, 
men som Holberg udtrykte det i fortalen til parallelbiografien mellem perseren Schach Abas og tyrkeren Soliman, så:

For at give grundige og oprigtige Afrisninger paa store Helte, deres naturlige Egenskaber, Dyder og Lyder [fejl], er fornødent at have ikke mindre Tiderne og Stederne, end Personerne for Øyen; thi en Dyd, som i Henseende til dens Øvelse er lige stor, er dog i Henseende til Personen, som øver den ikke altid af lige Vægt, ligesom en Lyde er altid en Lyde, men større og mindre, ligesom hvor og hos hvilke den findes (Holberg 1913-1963: XI, 175).

Holbergs vurdering af sine historiske personligheders adfærd var derfor styret af, hvad man kan kalde for en form for "betinget relativisme". I Schach Abas og Solimans tilfælde betød det, at deres middelmådighed rostes, mens deres til tider dubiøse adfærd lettere kunne undskyldes. Kort fortalt, så var de middelmådige helte, hvis karakteregenskaber ophøjedes pga. negativ arv og miljø - to faktorer, der ligeledes havde indflydelse på Holbergs dom over en af Heltehistoriers skurke.

\section{Skurk eller berømmelig? Holbergs gradbøjning af skinhellighed}

Antallet af biograferede skurke i Heltehistorier er ikke overvældende. Udover Ziska har Billeskov Jansen identificeret Mahomed (Muhammed) og Oran Zeb som en del af skurkegalleriet. Begge havde begået den samme forbrydelse ved at tilegne sig magt ved hjælp af et skinhelligt bedrag. Ud fra Holbergs kristne verdensopfattelse portrætteredes Mahomed som en rationelt tænkende bedrager og drømmer, der drevet af sit magtbegær stiftede en religiøs vranglære i form af Islam, som retfærdiggjorde uretfærdige krigshandlinger, røverier og endda flerkoneri. Et skinhelligt virke afstedkom dog ikke en automatisk stempling som skurk. Zoroaster, som Mahomed blev sammenlignet med, fik ikke en ligeså hård medfart og skildredes generelt positivt. Det tiltalte oplysningsmanden Holberg, at Zoroasters religion var fornuftsbaseret, hvorved han missionerede gennem rationel dialog, i modsætning til Mahomed som missionerede gennem fysisk tvang.

Oran Zeb var det samtidige eksempel på en skinhellig bedrager, 
der ved hjælp af politiske intriger og løgne, indespærringen af sin far samt mordet på sine brødre havde bemægtiget sig den mogulske trone (Holberg 1913-1963: XI, 45-73, 87-89). Oran Zebs karakterskildring led ligeledes under, at Holberg sammenparrede ham med den ægyptiske helt Saladin, der med visdom og ærlighed var blevet Ægyptens hersker, mens Oran Zeb: "var en saadan en, som gemeenligen kaldes Politicus, det er, fuld af Renker og Simulation" (Holberg 1913-1963: XI, 87). Oran Zebs eftermæle blev dog reddet af, at hans handlinger til dels kunne undskyldes pga. en manglende arvefølgeret i Mogulriget, som forårsagede hans skinhellige ageren. Holberg accepterede til gengæld ikke Saladins forsøg på at holde Ægyptens retmæssige herskere fra magten (Holberg 1913-1963: XI, 89), hvorved Saladin nok var helten, men han var ikke skurken overlegen på alle punkter.

\section{Heltehistoriers receptionshistorie}

Heltebistoriers popularitet kan afspejles i de adskillige genudgivelser fra henholdsvis 1742, 1753 og 1763, de senere genoptryk fra 18061807 og 1864-1865 (Ehrencron-Müller 1924-1935: X, 277-287), samt at udgivelsen af Adskillige Heltinders Og Navnkundige Damers Sammenlignede Historier. Efter Plutarchi Maade (1745) var direkte affødt af Heltehistoriers succes (Holberg 1913-1963: XIV, 399). Der var dog ikke kun tale om en dansk-norsk succes. Værket nød stor international udbredelse og udkom i fem tyske, to hollandske og en enkelt russisk oversættelse, om end den russiske udgave kun indeholdt de første seks dobbeltbiografier (Ehrencron-Müller 1924-1935: X, 287-299). Også i Sverige, hvor en decideret heltekult blandt svenske kunstnere og lærde gjorde sig gældende fra 1750'erne og fremefter (se Delblanc 1965), nød Heltehistorier stor interesse, hvilket afspejlede sig i hele tre mere eller mindre vellykkede efterligninger af værket (Gjörwell 1755-1756; Gjörwell 1757; Schönberg 1756).

Overordnet set tenderer både den nationale og internationale reception af Heltehistorier til at fokusere på Holbergs parallelbiografiske metode, mens helteidealerne og skurkedefinitioner er trådt mere i baggrunden (se f.eks. Gottsched 1756: 113; Holberg \& Scheibe 1764: CLII; Schönberg 1756; Toze 1776).

Et større fokus på Heltehistoriers helte- og skurkedefinitioner 
synes først at gøre sig gældende, da Henrik Stangerup i 1987 og 1988 forsøgte at vække danskernes interesse for værket med udgivelsen af Holberg's Heltehistorier. Holberg spandende som aldrig for. Bogprojektet, der skulle udkomme i fire bind, skrinlagdes efter andet bind, men i 1990 genoptog Stangerup projektet og udgav tobindsværket Holbergs helteog heltindehistorier. Den til tider tunge 1700-talstekst var af Stangerup omskrevet til nudansk, mens originalens parallelbiografiske metode og overordnede moralfilosofiske emner var bevaret. Til trods for flere positive anmeldelser i danske aviser (Billeskov Jansen 14.2.1991; Kistrup 31.1.1991; Tøjner 22.2.1991) blev den nyfordanskede genudgivelse ikke en salgsmæssig succes. Dette påpegede Stangerup selv, da han fem år senere $i$ en improviseret takketale, foranlediget af modtagelsen af Holberg-medaljen, håbede, at hæderen ville bidrage til, at antallet af solgte eksemplarer kunne snige sig op på hele 38 (Bredal 6.12.1995). Diskrepansen mellem de positive anmeldelser og det skuffende salgstal kan skyldes, at anmeldere såsom Poul Erik Tøjner, Jens Kistrup og F. J. Billeskov Jansen primært anmeldte værket ud fra deres litteraturvidenskabelige ståsted, mens Stangerup senere konstaterede, at salgstallet repræsenterede folks manglende interesse for værkets indhold (Stangerup 2003: 137).

\section{Konklusion}

På baggrund af det her fremforte må man konkludere, at Holbergs ægte helt var en fuldkommen mand eller kvinde, der var sat i verden for menneskets frelse. Men karakteren af denne frelse varierede efter de forskellige heltetyper: krigshelten var den nådige beskytter og ikke antikkens tapre hævner; den fuldendte regent ledte sit folk mod et højere civilisationstrin i form af viden, velstand og anseelse, mens Philosophus vejledte sine medmennesker gennem visdom. Holberg inkluderede desuden helte, der ikke kunne efterleve frelserkravet i streng forstand. De var helte, fordi de evnede at sætte sig ud over deres slette opdragelse og alligevel i et vist omfang handle glorværdigt.

Af Heltehistorier kan der ikke udledes en tilsvarende klar skurkedefinition. Man kan dog spore to skurketyper: den nådesløse hævner og den skinhellige bedrager.

Værket indeholdt samtidig en række biografier, hvis hovedpersoner hverken var helte eller skurke. Deres tilstedeværelse skyldes, at deres 
levned tjente til at understrege parallelbiografiernes moralfilosofiske emner. Holbergs ærinde var nemlig ikke først og fremmest biografisk, endsige litterært, men fra først til sidst moralfilosofisk og historisk. Prioriteringen kan være lidt svær at sluge for moderne læsere, men man må acceptere den, hvis man vil gøre sig håb om at forstå Holberg ret.

Til trods for at Stangerups genudgivelser af Heltehistorier floppede skal Heltehistoriers bidrag til nutidens definition af helte og skurke ikke underkendes. Nu til dags associerer vi sjældent statsmænd eller kvinder med helte, men vi kan lære af Holbergs idé om at præsentere et mere kulturelt mangfoldigt heltegalleri, der måske ikke, i nutidens nationale eller eurocentriske kontekst, opfylder vores krav for, hvad en helt er.

\section{Litteratur}

Amundsen, Leiv (1925): "Om Heltehistoriernes tilblivelse. Holbergs bruk av litterære kilder" i Francis Bull \& Carl S. Petersen (red.), Holberg Aarbog København: Gyldendalske Boghandel, Nordisk Forlag: s. 7-30.

Bang, Oluf (1743): "L. Holbergs Sammenlignede Helte-Historie" i Samling af Adskillige Nyttige og Opbyggelige Materier saa vel Gamle som Nye. IIII Stykke, København: s. 425-444.

Billeskov Jansen, F. J. (1938-1939): Holberg som Epigrammatiker og Essayist, København: Ejnar Munksgaards Forlag.

Brask, Peter (2006): "Holberg historiske helte" i Anne Elisabeth Sejten (red.), Helte og antibelte - en litteraturkritisk, mosaik, Frederiksberg: Roskilde Universitetsforlag, s. 59-97.

Bull, Francis (1913): Ludvig Holberg som historiker, Kristiania: H Aschehough \& Co.

Delblanc, Sven (1965): Ära och minne. Studier kring ett motivkomplex i 1700-talets litteratur, Stockholm: Albert Bonniers Förlag.

Ehrencron-Müller, Holger (1924-1935): Forfatterlexikon omfattende Danmark, Norge og Island indtil 1814, Købehavn: H. Aschehoug \& Co.

Gjörwell, Carl Christoffer (1754): Bref om Blandade Ämnen, Stockholm.

Gjörwell, Carl Christoffer (1755-1756): Stora och Namnkunniga Menniskjors Lefwernes-Beskrifningar Och Caracterer, Stockholm.

Gjörwell, Carl Christoffer (1757): Märkwärdiga Lefwernes-Beskerifningar, Stockholm. 
Gottsched, Johann Christoph (1756): Vorübungen der Beredsamkeit, zum Gebrauche der Gymnasien und größern Schulen, Leipzig.

Holberg, Ludvig (1913-1963): Ludvig Holbergs Samlede Skrifter, København: Gyldendalske Boghandel.

Holberg, Ludvig \& Scheibe, Johann Adolph (1764): Peter Paars, ein komisches Heldengedicht, København \& Leipzig.

Jensen, Anne E. (1984): Helte og Antihelte. Omkring Holbergs Olysses von Ithacia, København: Nyt Nordisk Forlag.

Jæger, Herman (1914): 'Norsk litteraturforskning i 1913” i Edda (Vol. 1), s. 196210.

Krüger, Paul (1968): Studier i komparativ litteratur, København: Gyldendal.

Langslet, Lars Roar (2002 [2001]): Den store ensomme. En biografi om Ludvig Holberg, København, Gyldendal.

Pedersen, Vibeke A. et al (2007): Danske litteraturs historie 1100-1800, København: Gyldendal.

Plutarch \& Kind, Johann Christoph (1745): Plutarchs von Chäronea Lebens-Beschreibungen der berühmten Männer Theseus, Romulus, Lykurgs, Numa, Solons und P. Val. Publicola, Leipzig.

Schönberg, Anders (1756): Hjältars Sammanliknade Historier på Baron Holbergs Sät, Stockholm: Lars Salvii Förlag.

Stangerup, Henrik (1987-1988): Holberg's Heltehistorier. Holberg spandende som aldrig for, København: Peter Asschenfeldt's Forlag.

Stangerup, Henrik (1990): Holbergs helte- og heltindehistorier, København: Lindhardt og Ringhof.

Stangerup, Henrik (2003): Tvartimod!: levned og meninger 1956-98, København: Gyldendals Bogklubber.

Toze, Eobald (1776): Don Carlos und Alexei, Luines und Buckingham, ein Versuch in verglichenen Lebensbeschreibungen, Greifswald.

\section{Avisartikler}

Billeskov Jansen, F. J. (14.2.1991): 'Holberg genopstået” i Politiken, s. 8.

Bredal, Bjørn (6.12.1995): "Henrik Stangerup og Holberg” i Politiken, Kultur og debat, s. 6.

Kistrup, Jens (31.1.1991): "Heltene, heltinder og Holberg" i Berlingske Tidende, 3. sektion Magasin, s. 6.

Tøjner, Poul Erik (22.2.1991): "Holdbar Holberg" i Weekendavisen, 3. sektion Bøger, s. 6. 
